\title{
Pengaruh Intervensi Konseling Feeding Rules dan Stimulasi Terhadap Status Gizi dan Perkembangan Anak di Posyandu Kabupaten Jayapura
}

\author{
Darwati, ${ }^{*}$ Maria Mexitalia, ${ }^{* *}$ Soemedi Hadiyanto, ${ }^{* *}$ Fitri Hartanto, ${ }^{* *}$ S.A. Nugraheni ${ }^{* * *}$ \\ "Staf Balai Pelatihan Tenaga Kesehatan Provinsi Papua di Abepura-Jayapura, "Bagian/SMF Ilmu Kesehatan \\ Anak Fakultas Kedokteran Universitas Diponegoro/RSUP Dr. Kariadi Semarang, ${ }^{* * *}$ Widyaiswara Balai \\ Pelatihan Tenaga Kesehatan Provinsi Papua di Jayapura, ${ }^{* * * *}$ Fakultas Kesehatan Masyarakat Universitas \\ Diponegoro Semarang
}

Latar belakang. Kesulitan makan dalam jangka waktu lama dapat menimbulkan gagal tumbuh dan keterlambatan perkembangan anak.

Tujuan. Mengkaji dampak intervensi (konseling gizi dengan metode feeding rules dan stimulasi) terhadap status gizi dan perkembangan anak di Posyandu Kabupaten Jayapura.

Metode. Penelitian quasi experiment pre post test group dilakukan pada anak usia 6-24 bulan dengan kesulitan makan, di 6 Posyandu Kecamatan Sentani Kabupaten Jayapura. Konseling dengan metode feeding rules dan stimulasi dengan SDIDTK (Stimulasi, Deteksi dan Intervensi Dini Tumbuh Kembang) selama 4 bulan (Agustus-Desember 2012), diberikan oleh kader Posyandu terlatih kepada ibu / pengasuh dan anaknya. Status gizi setelah intervensi diukur berdasarkan skor WAZ (Weight for Age z-score), HAZ (Height for Age z-score), dan WHZ (Weight for Height z-score) sedangkan perkembangan diukur dengan data skor KPSP (kuesioner pra skrining perkembangan) diuji dengan menggunakan uji t berpasangan dan uji Wilcoxon.

Hasil. Subyek berjumlah 119 anak (58,8\% laki-laki), 83,2\% di antaranya mengalami kesulitan makan kategori inappropriate feeding practice. Peningkatan bermakna skor WAZ -0,59 (SB 0,93) menjadi -0,45

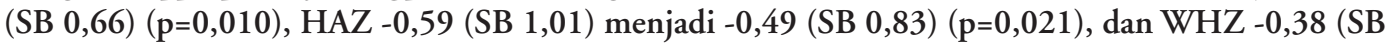
$0,94)$ menjadi -0,28 (SB 0,77) ( $\mathrm{p}=0,014)$, dan skor KPSP dari 8,76 (SB 1,00) menjadi 9,11 (SB 0,72) $(\mathrm{p}=0,002)$ antara sebelum dan sesudah intervensi.

Kesimpulan. Terdapat peningkatan secara bermakna status gizi dan perkembangan pada anak dengan kesulitan makan usia 6-24 bulan setelah diberikan konseling gizi dengan metode feeding rules dan stimulasi SDIDTK selama 4 bulan di Posyandu. Sari Pediatri 2014;15(6):377-84.

Kata kunci: kesulitan makan, konseling feeding rules, stimulasi SDIDTK, status gizi, perkembangan

\section{Alamat korespondensi:}

DR. Dr. Maria Mexitalia, Sp.A(K). Bagian/SMF Kesehatan Anak Fakultas Kedokteran Universitas Diponegoro/RSUP Dr. Kariadi. Jl. Dr. Sutomo 16-18 Semarang. Telp./Fax. (024) 8414296.E-mail: maria_mexitalia@ yahoo.com

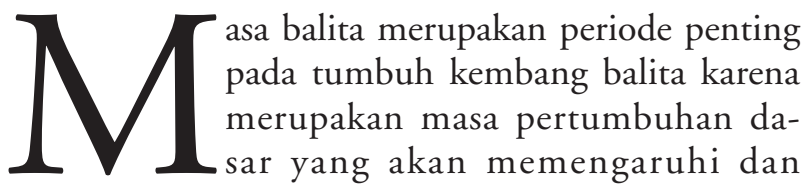


menentukan perkembangan anak selanjutnya. Pertumbuhan fisik masa balita berhubungan erat dengan perkembangan mental anak terutama pada usia di bawah dua tahun. Seorang anak yang berstatus gizi baik dan sehat akan merespon perubahan lingkungan lebih aktif dan selanjutnya mempercepat perkembangan mental anak. Intervensi kombinasi berbagai aktifitas seperti gizi, kesehatan, dan stimulasi akan berdampak lebih bermakna terhadap perkembangan anak. Gizi kurang pada usia 0-24 bulan dapat menyebabkan gangguan tumbuh kembang otak permanen. ${ }^{1} \mathrm{Se}$ besar $30,8 \%$ anak berusia $6-18$ bulan mengalami keterlambatan perkembangan motorik kasarnya. ${ }^{2}$

Gizi merupakan determinan penting tumbuh kembang anak, tetapi gizi saja tidak cukup, rangsangan juga diperlukan untuk pematangan fungsi tubuh. Pemberian makanan maupun stimulasi yang efektif hanya mungkin diperoleh anak jika ibu atau pengasuh mempunyai pengetahuan, sikap, dan motivasi yang berkenaan dengan pemberian makanan dan stimulasi tersebut. Pendidikan gizi dan stimulasi melalui konseling merupakan kombinasi upaya yang cukup efektif dalam merubah perilaku ibu/pengasuh. ${ }^{1}$

Kesulitan makan merupakan kebiasaan dan perilaku makan pada anak yang perlu diperhatikan oleh orangtua maupun praktisi kesehatan karena memiliki efek yang merugikan bagi pengasuh maupun anak. ${ }^{3,4}$ Pemberian konseling pada orangtua yang mencakup feeding rules dapat membantu anak belajar mengatur dan mengatasi masalah makannya sendiri. ${ }^{5}$ Status gizi dapat menggambarkan kecukupan asupan nutrisi. ${ }^{6}$ Mengklasifikasi ganggguan makan anak ke dalam kelompok berdasarkan cara anak menerima nutrisi dapat diperoleh riwayat makan anak. Hal ini membantu menentukan tata laksana, mengidentifikasi cara pemberian dukungan kepada pengasuh, dan memantau status gizi anak. ${ }^{7}$ Prevalensi gangguan makan anak usia 4-6 tahun di Jakarta 33,6\%; 44,5\% di antaranya menderita malnutrisi ringan hingga sedang dan 79,2\% telah berlangsung lebih dari 3 bulan. ${ }^{8}$

Dengan demikian, maka konseling dan stimulasi merupakan dua intervensi penting untuk memaksimalkan pertumbuhan dan perkembangan anak yang merupakan dua proses yang berbeda, tetapi saling terkait satu dengan lainnya. Penelitian tentang pengaruh intervensi konseling metode feeding rules dan stimulasi telah dilakukan di negara lain. Namun, penelitian serupa masih jarang dilakukan di Indonesia, khususnya di Jayapura. Oleh karena itu, diperlukan suatu penelitian yang bertujuan untuk mengkaji dampak intervensi (konseling gizi dengan metode feeding rules dan stimulasi) terhadap perubahan status gizi dan perkembangan anak usia 6-24 bulan di Posyandu Kabupaten Jayapura.

\section{Metode}

Metode penelitian dengan studi quasi experiment non randomized pre post test group dilakukan pada anak usia 6-24 bulan dengan kesulitan makan menurut ibu/ pengasuh. Variabel bebas adalah konseling orang tua/ pengasuh anak usia 6-24 bulan dan stimulasi anak usia 6-24 bulan. Variabel terikat adalah perubahan status gizi anak usia 6-24 bulan (berat badan, panjang badan, status gizi) dan perkembangan anak usia 6-24 Bulan. Ethical Clearance dari Komisi Etik Penelitian Kesehatan Fakultas Kedokteran Universitas Diponegoro / RSUP Dr. Kariadi Semarang bernomor : 378/EC/FK/RSDK/ 2012.

Penelitian dilaksanakan selama bulan AgustusDesember 2012 di dua Posyandu Puskesmas Harapan (Posyandu Asei Besar dan Nendali) di Distrik Sentani Timur dan empat Posyandu Puskesmas Sentani (Posyandu Ifar Besar, Kehiran 1, Furia dan Yahim) di Distrik Sentani Kabupaten Jayapura, terhadap 119 anak/sampel anak usia 6-24 bulan dengan kesulitan makan menurut ibu/pengasuh. Konseling dengan feeding rules dan stimulasi dengan SDIDTK (Stimulasi, Deteksi dan Intervensi Dini Tumbuh Kembang) diberikan oleh kader Posyandu terlatih didampingi petugas Puskesmas terlatih kepada ibu/pengasuh dan anaknya.

Hasil perhitungan besar sampel diperoleh 82 anak usia 6-24 bulan. Cadangan sampel dipersiapkan $15 \%(15 \% \times 82)+82=94,3$ dibulatkan menjadi 95 subjek untuk memperhitungkan droup out. Setiap Posyandu diharapkan diperoleh 20 sampel sehingga total sampel adalah $20 \times 6$ Posyandu $=120$ subjek. Sampel adalah bayi/anak berusia 6-24 bulan yang memenuhi kriteria inklusi dan tidak memenuhi kriteria eksklusi serta terdaftar di Posyandu. Kriteria inklusi adalah anak berusia 6-24 bulan dengan kesulitan makan menurut ibu/pengasuh dan tidak mengalami infeksi selama mengikuti penelitian, dan orang tuanya setuju menjadi responden dan anaknya menjadi subjek. Kriteria eksklusi adalah anak yang memiliki abnormalitas struktural, memiliki gangguan perkembangan neurologis, menderita penyakit kronik 
dan sistemik, menderita penyakit kongenital, dan menderita penyakit keganasan.

Data berat badan diukur dengan timbangan berat badan Tanita BC 541 dengan tingkat ketelitian 0,1 $\mathrm{kg}$, apabila bayi belum bisa berdiri diukur dengan timbangan bayi merek Tanita BD 1380. Tinggi badan diukur dengan menggunakan alat ukur panjang Badan Seca 210 Mobile Measuring mat for babies an toddlers dengan ketelitian $0,1 \mathrm{~cm}$. Penentuan status gizi dilakukan dengan cara mengklasifikasikan status gizi menggunakan standar baku z-score WHO. Perkembangan diukur dengan instrumen stimulasi, deteksi dan intervensi dini tumbuh kembang anak (SDIDTK) komponen KPSP (kuesioner pra skrining perkembangan). ${ }^{9}$ Pengukuran KPSP dibantu alat permainan edukatif (APE) sesuai umur standar BKKBN tahun 2011.

Perbandingan data pengukuran awal dan akhir dari skor WAZ (weight for age z-score), HAZ (height for age z-score), dan WHZ (weight for height z-score) serta data skor KPSP (kuesioner pra skrining perkembangan) diuji dengan menggunakan uji t berpasangan (paired t test) atau uji Wilcoxon, setelah sebelumnya dilakukan uji normalitas Liliefort (Kolmogorov Smirnov). Pengolahan data menggunakan program SPSS for windows dan program Child Growth Standard WHO Antro 2011 ver 3.2.2. Child Growth Standard WHO Antro 2011 ver 3.2.2 digunakan untuk mengolah data hasil pengukuran antropometri sehingga dapat ketahui status gizi setiap anak.

Tabel 1. Karakteristik subjek ( $\mathrm{n}=119)$

\begin{tabular}{|c|c|c|c|}
\hline \multirow{2}{*}{\multicolumn{4}{|c|}{$\begin{array}{l}\text { Variabel } \\
\text { Jenis kelamin anak (\%) }\end{array}$}} \\
\hline & & & \\
\hline Laki-laki & 70 & $(58,8)$ & \\
\hline Perempuan & 49 & $(41,2)$ & \\
\hline Anak (bulan) & & & $14,08(\mathrm{SB} 5,40)$ \\
\hline \multicolumn{4}{|l|}{ Orang tua (tahun) } \\
\hline Ayah & & & $31,66(\mathrm{SB} 8,10)$ \\
\hline Ibu & & & $28,11(\mathrm{SB} 7,50)$ \\
\hline \multicolumn{4}{|l|}{ Pendidikan orang tua (\%) } \\
\hline \multicolumn{4}{|l|}{ Pendidikan ayah } \\
\hline Tidak sekolah & 2 & $(1,7)$ & \\
\hline Tidak tamat SD & 2 & $(1,7)$ & \\
\hline Tamat SD & 5 & $(4,2)$ & \\
\hline Tamat SMP & 16 & $(13,4)$ & \\
\hline Tamat SMU & 76 & $(63,9)$ & \\
\hline Tamat Perguruan Tinggi & 18 & $(15,1)$ & \\
\hline \multicolumn{4}{|l|}{ Pendidikan Ibu } \\
\hline Tidak sekolah & 0 & $(0,0)$ & \\
\hline Tidak tamat SD & 2 & $(1,7)$ & \\
\hline Tamat SD & 9 & $(7,6)$ & \\
\hline Tamat SMP & 27 & $(22,7)$ & \\
\hline Tamat SMU & 64 & $(53,8)$ & \\
\hline Tamat perguruan tinggi & 17 & $(14,3)$ & \\
\hline \multicolumn{4}{|l|}{ Pekerjaan orang tua $(\%)$} \\
\hline \multicolumn{4}{|l|}{$\begin{array}{l}\text { Pekerjaan ayah } \\
\text { Palut }\end{array}$} \\
\hline Tidak bekerja & 1 & $(0,8)$ & \\
\hline Nelayan & 8 & $(6,7)$ & \\
\hline PNS/TNI/Polri/Pensiun/BUMN & 37 & $(37,7)$ & \\
\hline Petani & 11 & $(9,3)$ & \\
\hline Sopir/ojek & 16 & $(13,5)$ & \\
\hline Tukang/buruh/satpam/pengrajin & 35 & $(29,5)$ & \\
\hline Pendeta & 3 & $(2,5)$ & \\
\hline \multicolumn{4}{|l|}{ Pekerjaan Ibu } \\
\hline Ibu rumah tangga & 95 & $(79,5)$ & \\
\hline Nelayan $\quad 00$ & 5 & $(4,2)$ & \\
\hline PNS/TNI/Polri & 10 & $(8,4)$ & \\
\hline Pedagang & 7 & $(5,9)$ & \\
\hline Pendeta & 2 & $(1,7)$ & \\
\hline
\end{tabular}




\section{Hasil}

Didapatkan 120 anak usia 6-24 bulan yang memenuhi kriteria inklusi di 6 Posyandu Kecamatan Sentani Kabupaten Jayapura. Pemantauan lanjutan tidak dapat dilakukan pada 1 anak karena pindah alamat sehingga terdapat 119 anak yang terlibat hingga akhir penelitian. Subyek terdiri dari $70(58,8 \%)$ anak laki-laki dan 49 $(41,2 \%)$ anak perempuan dengan rerata umur 14,08 $($ SB 5,40) bulan.

Sebagian besar anak usia 6-24 bulan didiagnosis sebagai kesulitan makan inappropriate feeding practice yaitu praktik pemberian makan pada anak yang tidak sesuai dengan umur ataupun tahapan perkembangan $99(83,2 \%)$ anak, sedangkan parental misperception yaitu masalah makan yang timbul karena orangtua terlalu khawatir atau orangtua mengira porsi makan anak terlalu sedikit hanya $20(16,8 \%)$ anak.

Setelah 4 bulan dilakukan intervensi konseling dengan feeding rules dan stimulasi dengan SDIDTK, terdapat peningkatan secara bermakna pada skor WAZ dari -0,59 (SB 0,93) sebelum intervensi menjadi -0,45 (SB 0,66) sesudah intervensi $(\mathrm{p}=0,010)$, HAZ dari $-0,59$ (SB 1,01) sebelum intervensi menjadi $-0,49$ (SB 0,83) sesudah intervensi $(\mathrm{p}=0,021)$, dan WHZ dari -0,38 (SB 0,94) sebelum intervensi menjadi -0,28 (SB 0,77) sesudah intervensi $(\mathrm{p}=0,014)$. Sedangkan skor KPSP juga meningkat secara bermakna dari 8,76 (SB 1,00) sebelum intervensi menjadi 9,11 (SB 0,72) sesudah intervensi $(\mathrm{p}=0,002)$.

Gambar 1 menunjukkan grafik rerata skor WAZ, HAZ dan WHZ cenderung meningkat setiap bulannya. Rerata skor WAZ pada awal pengukuran adalah -0,59 (SB 0,93), dan cenderung meningkat pada pengukuran ke 2, ke 3, ke 4 serta pada pengukuran akhir meningkat menjadi -0,45 (SB 0,66). Rerata skor HAZ pada awal pengukuran adalah $-0,59$ (SB 1,01), dan cenderung meningkat pada pengukuran ke 2, ke 3, ke 4 serta pada pengukuran akhir meningkat menjadi -0,49 (SB 0,83). Rerata skor WHZ pada awal pengukuran adalah -0,38

Tabel 2. Perbandingan data sebelum dan sesudah dilakukan intervensi

\begin{tabular}{|c|c|c|c|}
\hline \multirow{2}{*}{ Variabel } & Awal pengamatan & Akhir pengamatan & \multirow[b]{2}{*}{$\mathrm{p}$} \\
\hline & \multicolumn{2}{|c|}{ Rerata (SB) } & \\
\hline Umur (bulan) & $14,08(\mathrm{SB} 5,40)$ & $18,06(\mathrm{SB} 5,39)$ & \\
\hline Berat badan (kg) & $9,13(\mathrm{SB} 1,48)$ & $10,14(\mathrm{SB} 1.33)$ & $<0,001^{\text {b) }}$ \\
\hline Panjang badan $(\mathrm{cm})$ & $74,58(\mathrm{SB} 5,59)$ & $79,10(\mathrm{SB} 4,88)$ & $<0,001^{\mathrm{b})}$ \\
\hline Skor WAZ & $-0,59(\mathrm{SB} 0,93)$ & $-0,45(\mathrm{SB} 0,66)$ & $0,010^{\mathrm{b})}$ \\
\hline Skor HAZ & $-0,59(\mathrm{SB} 1,01)$ & $-0,49(\mathrm{SB} 0,83)$ & $0,021^{\mathrm{b})}$ \\
\hline Skor WHZ & $-0,38($ SB 0,94) & $-0,28($ SB 0,77) & $0,014^{\mathrm{a})}$ \\
\hline Skor KPSP & $8,76(\mathrm{SB} 1,00)$ & $9,11(\mathrm{SB} 0,72)$ & $0,002^{\mathrm{b})}$ \\
\hline Skor Feeding Rules & $8,07(\mathrm{SB} 1,15)$ & $8,39(\mathrm{SB} 1,00)$ & $0,003^{\mathrm{b})}$ \\
\hline
\end{tabular}

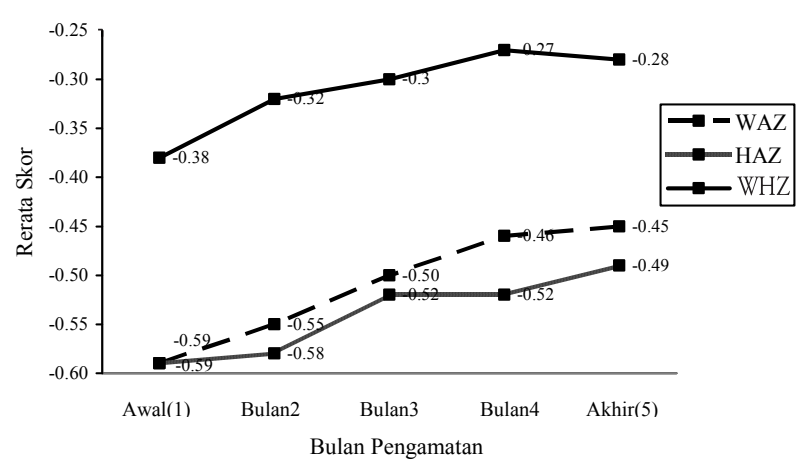

Gambar 1. Rerata hasil pengamatan per bulan skor WAZ, HAZ dan WHZ

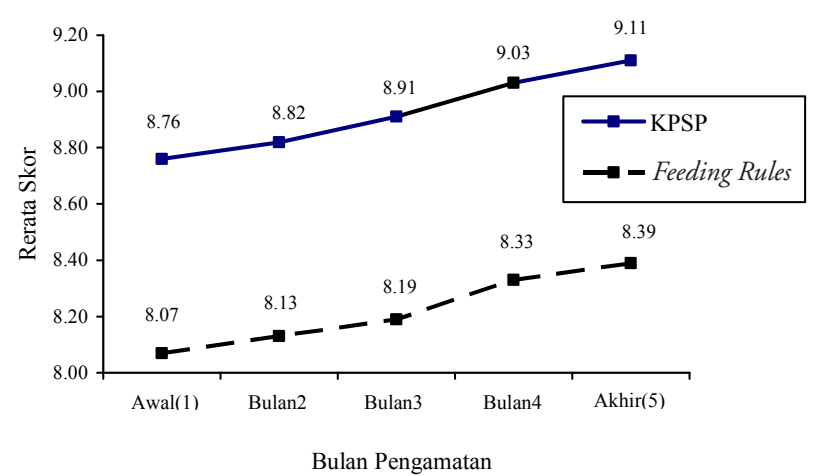

Gambar 2. Hasil pengamatan per bulan rerata skor feeding rules dan status perkembangan 
Darwati dkk: Pengaruh intervensi konseling feeding rules dan stimulasi terhadap status gizi dan perkembangan anak

(SB 0,94), dan cenderung meningkat pada pengukuran ke-2, ke-3, ke-4 serta meningkat menjadi -0,28 (SB $0,77)$ pada pengukuran akhir.

Gambar 2 menunjukkan grafik rerata skor feeding rules dan status perkembangan anak usia 6-24 bulan dengan pengukuran skor KPSP yang cenderung meningkat setiap bulannya. Rerata skor feeding rules pada awal pengukuran 8,07 (SB 1,15), dan cenderung meningkat pada pengukuran ke-2, ke-3 dan ke-4 serta pada pengukuran akhir meningkat menjadi 8,39 (SB 1,00). Rerata KPSP pada awal pengukuran 8,76 (SB $1,00)$, dan cenderung meningkat pada pengukuran ke2, ke-3, ke-4 serta pada pengukuran akhir meningkat menjadi 9,11 (SB 0,72).

\section{Pembahasan}

Rerata usia anak usia 6-24 bulan adalah 14,08 (SB $5,40)$ bulan yang merupakan usia dengan kebutuhan asupan gizi yang penting, sebab usia bayi merupakan landasan penting yang akan menentukan pertumbuhan dan perkembangan untuk fase berikutnya. Secara luas, usia 0-3 tahun merupakan periode kritis dalam proses tumbuh kembang anak, rentang usia periode emas (golden period) untuk landasan peningkatan potensi bayi maupun anak dikemudian hari. ${ }^{10}$ Bayi dan anak yang memiliki masalah makan berdampak pada energi dan nutrisi yang tidak terpenuhi sehingga mengakibatkan terhambatnya proses pertumbuhan anak kelak..$^{5,11}$

Sebagian besar anak usia 6-24 bulan pada penelitian kami didiagnosis sebagai kesulitan makan; inappropriate feeding practice 99 (83,2\%) anak, sedangkan parental misperception 20 (16,8\%) anak. Penelitian Kadarhadi dkk, ${ }^{19}$ di Semarang, didapatkan 92,7\% anak memiliki masalah makan jenis inappropriate feeding practice. Hal tersebut sesuai dengan pernyataan UKK Nutrisi dan Penyakit Metabolik bahwa inappropriate feeding practice merupakan salah satu jenis kesulitan makan yang banyak ditemukan di Indonesia. Definisi kesulitan makan itu sendiri adalah merupakan kegagalan yang bersifat menetap pada anak untuk memperoleh sejumlah asupan makanan yang memadai. ${ }^{4,12,13}$ Kesulitan makan merupakan faktor risiko kerentanan terhadap kekurangan gizi pada anak. ${ }^{14}$

Inappropriate feeding practice merupakan praktik pemberian makan pada anak yang tidak sesuai dengan umur maupun tahapan perkembangannya. ${ }^{15}$ Feeding practice yang tidak benar sering ditemui pada penelitian kami adalah pemberian makan anak yang tidak sesuai dengan tahapan usia. Pada umumnya, feeding practice yang tidak benar dilakukan oleh orangtua/pengasuh adalah pemberian makan anak sambil bermain dan menonton televisi, sehingga anak tidak fokus terhadap makanannya dan tidak dapat menghabiskan makanannya. ${ }^{5}$ Pengenalan MPASI yang tidak tepat waktu juga dapat mengakibatkan gangguan tumbuh kembang pada anak. Pemberian MPASI yang terlalu dini ( $<4$ bulan) berisiko diare, sedangkan pemberian MPASI yang terlambat (>7bulan) mengakibatkan defisiensi zat besi serta berpotensi terjadinya gagal tumbuh. ${ }^{16}$

Rerata skor feeding rules 8,07 (SB 1,15) sebelum intervensi dengan konseling feeding rules menjadi 8,39 (SB 1,00) sesudah intervensi dengan tingkat kemaknaan $\mathrm{p}=0,003$ menunjukkan pemberian edukasi mengenai basic feeding rules terhadap orang tua/pengasuh yang terlibat dalam proses pemberian makan anak merupakan intervensi yang dapat dilakukan untuk mengatasi feeding practice yang tidak benar, terutama edukasi pada orangtua/pengasuh yang terlalu cemas atau mengira porsi makan anak terlalu sedikit meskipun pedoman pemberian makan anaknya (feeding practice) sudah benar dan tidak terkecuali kesulitan makan jenis inappropriate feeding practice. ${ }^{17}$ Peningkatan skor feeding rules pada penelitian kami juga dimaknai sebagai efektifitas dari intervensi konseling feeding rules. Sasaran edukasi di lokasi penelitian adalah pada ibu kandung sebagai pengasuh $(79,5 \%)$ dan selebihnya adalah nenek atau orang tua angkat sebagai pengasuh.

Hasil penelitian kami menunjukkan rerata skor WAZ, HAZ, dan WHZ mengalami peningkatan setelah dilakukan intervensi. Perubahan WAZ yang lebih bermakna dibandingkan perubahan HAZ karena WAZ merupakan indikator status gizi saat sekarang (current nutrition status) yang dapat digunakan sebagai pemantau pertumbuhan (growth monitoring), ${ }^{6,18}$ sedangkan HAZ yang merupakan indikator status gizi di masa lampau. Perubahan HAZ yang lebih bermakna memerlukan intervensi dengan durasi waktu yang cukup panjang (4 bulan). Perubahan rerata skor WHZ awal dan akhir pengamatan bermakna karena perubahan rerata berat badan lebih bermakna dibandingkan perubahan panjang badan. Penelitian tentang pertumbuhan dan makan anak di Cina ditunjukkan peningkatan skor WAZ dan HAZ 
yang lebih baik pada kelompok yang diberi edukasi dibandingkan kelompok kontrol. ${ }^{17}$ Penelitian di Bogor ${ }^{17}$ juga ditunjukkan pertambahan berat badan dan panjang badan, status gizi panjang badan terhadap umur pada perlakuan dengan penyuluhan gizi dan stimulasi. Penelitian di Semarang, ${ }^{19}$ ditunjukkan terdapat perbedaan status gizi anak dengan kesulitan makan sebelum dan sesudah konseling dengan feeding rules pada skor HAZ.

Rerata status perkembangan anak usia 6-24 bulan dengan pengukuran skor KPSP meningkat sebelum dan setelah intervensi. Apabila dikelompokkan menurut jumlah skor maka terjadi perbedaan prevalensi status perkembangan anak dengan skor 7 dan 8 (kategori status perkembangan anak meragukan/M) dari 46,2\% (55 anak) pada awal pengamatan dan menurun menjadi $21,0 \%$ (25 anak) pada pengukuran akhir setelah dilakukan intervensi. Jumlah skor 9 dan 10 menunjukkan perkembangan anak sesuai dengan tahap perkembangannya $(S)$. Prevalensi skor 7 dan 8 (kategori status perkembangan anak meragukan/M) yang masih tinggi pada akhir pengamatan menunjukkan bahwa intervensi ini perlu dilakukan secara berkesinambungan.

Penelitian di Cimahi ${ }^{20}$ dan Bogor ${ }^{1}$ ditunjukkan intervensi stimulasi dan konseling memberikan dampak positif terhadap pertumbuhan dan perkembangan anak. Anak dengan status gizi baik dapat saja mengalami gangguan perkembangan. Gangguan perkembangan sudah terjadi pada anak berumur 6 bulan sehingga upaya pencegahan dan peningkatan kualitas perkembangan sangat diperlukan. Intervensi terpadu suplementasi gizi, penyuluhan, dan stimulasi sangat berpengaruh terhadap pertumbuhan dan perkembangan anak.

Hasil tersebut menunjukkan peran penting intervensi stimulasi dan konseling gizi dengan metode feeding rules. Penelitian lain telah menunjukkan peran penting zat gizi tidak saja pada pertumbuhan fisik tubuh, tetapi juga dalam pertumbuhan otak, perkembangan perilaku, motorik, dan kecerdasan. ${ }^{21}$ Kekurangan gizi pada masa kehamilan dan anak usia dini menyebabkan keterlambatan dalam pertumbuhan fisik, perkembangan motorik, dan gangguan perkembangan kognitif. Selain itu, akibat kekurangan gizi dapat berdampak pada perubahan perilaku sosial, berkurangnya perhatian dan kemampuan belajar sehingga berakibat pada rendahnya hasil belajar. Penelitian lain menyimpulkan bahwa intervensi gizi hanya akan efektif jika dilakukan selama kehamilan dan 2-3 tahun pertama kehidupan anak. ${ }^{22}$
Hubungan yang erat antara pertumbuhan fisik dengan perkembangan mental anak terutama pada usia di bawah dua tahun. ${ }^{1}$ Seorang anak yang berstatus gizi baik dan sehat akan merespon perubahan lingkungan lebih aktif dan selanjutnya mempercepat perkembangan mental anak. Intervensi kombinasi berbagai aktifitas, seperti gizi, kesehatan, dan stimuli akan berdampak lebih terhadap perkembangan anak. Gizi kurang pada usia 0-24 bulan dapat menyebabkan gangguan tumbuh kembang otak permanen. Penyederhanaan program implementasi sangat diperlukan mengingat pelaksanaan program SDIDTK di Puskesmas dan jaringannya masih terbatas pada deteksi dini penyimpangan pertumbuhan, sedangkan deteksi dini penyimpangan perkembangan, penyimpangan mental emosional, dan stimulasi sesuai usia anak masih belum dilaksanakan. ${ }^{23}$

Perubahan perilaku merupakan faktor utama penentu keberhasilan dalam pencegahan terjadinya gangguan tumbuh kembang yang berdampak jangka panjang. ${ }^{1}$ Secara keseluruhan, konseling gizi dengan metode feeding rules dan stimulasi merupakan kunci keberhasilan program terpadu dalam pencegahan gangguan tumbuh kembang pada anak di bawah dua tahun. Faktor keberhasilan mendidik ibu sebagai stimulator di rumah, ketepatan kurikulum, dan frekuensi pertemuan di Posyandu, kemampuan kader Posyandu sebagai penyuluh, merupakan prasyarat keberhasilan program selain materi, metode, dan alat bantu yang efektif.

Hasil penelitian kami juga menunjukkan bahwa program stimulasi dan konseling secara sederhana di Posyandu berdampak positif terhadap perkembangan anak yang dapat di laksanakan di pedesaan dengan biaya yang rendah dan tidak memerlukan ruangan khusus. Stimulasi dan konseling tidak cukup hanya dilakukan di Posyandu, penulis telah merancang panduan stimulasi pada bayi $0-12$ bulan/12-24 bulan dan panduan konseling dengan kesulitan makan pada anak. Panduan berupa leaflet tersebut dapat di gunakan ibu/pengasuh di rumah. Penyusunan leaflet berpedoman pada buku program SDIDTK. ${ }^{9}$

Alat permainan merupakan faktor determinan terhadap perkembangan anak. Intervensi stimulasi pada penelitian kami mempergunakan alat permainan edukatif (APE) standarisasi BKB kit. Alat permainan edukatif terutama untuk anak di bawah 2 tahun dapat di buat sendiri atau membeli. Pada penelitian kami, kader Posyandu terlatih dibekali dengan APE sederhana untuk anak di bawah dua tahun, sedangkan 
Darwati dkk: Pengaruh intervensi konseling feeding rules dan stimulasi terhadap status gizi dan perkembangan anak

masing-masing Posyandu diberikan APE standarisasi BKB kit.

\section{Kesimpulan}

Terdapat perbedaaan status gizi anak usia 6-24 bulan antara sebelum dan sesudah diberi konseling gizi dengan metode feeding rules selama 4 bulan di Posyandu, dilihat dari skor WAZ, HAZ, dan WHZ, serta status perkembangan anak berdasarkan skor KPSP. Penelitian lebih lanjut diperlukan dengan menggunakan kontrol untuk mengurangi bias hasil penelitian, dan menggunakan variabel lain misalnya pola pemberian makan anak usia 6-24 bulan, pemberian susu formula/MP ASI, perilaku, dan pola pemberian makan keluarga, intake konsumsi anak, pengetahuan dan sikap ibu/pengasuh.

\section{Ucapan Terimakasih}

Penelitian ini dibiayai oleh Hibah dari USAID-IRD-SERASI Project DUNS 727177607 tanggal 22 Mei 2012 kepada Yayasan Amalia Jaya Abadi (YAJA) Jayapura. Peneliti mengucapkan terimakasih kepada USAID dan SERASI untuk dana yang diberikan, Kepala Puskesmas Harapan dan Puskesmas Sentani Kabupaten Jayapura serta seluruh staf dan kader Posyandu di wilayah tersebut atas partisipasinya dalam penelitian ini.

\section{Daftar pustaka}

1. Herawati N. Pengaruh suplemen MPASI, penyuluhan gizi dan stimulasi terhadap tumbuh kembang bayi 6-12 bulan [disertasi]. Bogor : Institut Pertanian Bogor, 2005.

2. Kartika V, Prihartini S, Syafrudin, Jahari AB, 2000. Pola pemberian makan anak (6-18 bulan) dan hubungannya dengan pertumbuhan dan perkembangan pada anak keluarga miskin dan tidak miskin. PGM 2000;23:3747.

3. Faye CP, Claire VF, Carolinae M, Food avoidance in children : The influence of maternal feeding practices and behaviors. Appetite 2011;57:683-92.

4. Piazza CC, Carroll-Hernandez TA. Asessment and treatment of pediatric feeding disorders. Dalam: Tremblay RE, Barr RG, Peters RDeV, penyunting. Encycloperid on early childhood development. Montreal:
Center of Excelllence for Early Chilhood Development 2004. h.1-7.

5. Chatoor I. Diagnosis and treatment of feeding disorders, in infant, toddlers, and young children. Washington DC: Zero to three; 2009.

6. FKM UI, Gizi dan Kesehatan Masyarakat/Departemen Gizi dan Kesehatan Masyarakat. Jakarta: PT Raja Grafindo Persada 2008. h.275-98.

7. Greer AJ, Gulotta CS, Masler EA, Laud RB. Caregiver stress and outcomes of children with pediatric feeding disorders treated in an intensive interdisciplinary program. J Pediatr Psychol 2008;33:612-20.

8. Lubis G. Masalah makan pada anak. Majalah Kedokteran Andalas 2011;29: Januari-Juni.

9. Kementerian Kesehatan RI. Pedoman Pelaksanaan Stimulasi, Deteksi dan Intervensi Dini Tumbuh Kembang Anak di Tingkat Pelayanan Kesehatan Dasar. Jakarta: Depkes RI 2010.

10. Selina H, Fitri H, Farid AR. Stimulasi, deteksi, dan intervensi dini tumbuh kembang anak. Dalam: Dadiyanto DW, Muryawan MH, Anindita, penyunting. Buku ajar Ilmu Kesehatan Anak. Edisi pertama, Semarang: Badan Penerbit Universitas Diponegoro; 2011.h 65-6.

11. Field D, Garland M, Williams K. Correlates of spesific childhood feeding problems. J Pediatric Child Health 2003;39:299-304.

12. Shore B, Piazza C, 1997. Pediatric feeding disorders. Dalam: Konarski EA, Favell JE, Favell JE, penyunting. Manual for the assessment and treatment of the behavior of people with mental retardation. New York: Guilford;1997. h.65-89.

13. Winters NC. Feeding problems in infancy and ealy childhood. Primary Psychiatry 2003;10:30-4.

14. Yousafzai, Aisha K., Suzanne Filteau and Sheila Wirz. Feeding difficulties in disabled children leads to malnutrition: experience in an Indian slum. Br J Nutr 2003;90:1097-1106.

15. Burklow KA, Phelps AN, Schultz JR, McConnell K, Rudolph C. Classifying complex pediatric feeding disorders. J Pediatr Gastroenterol Nutr 1998;27:143-7.

16. Mexitalia M. Kesulitan makan pada anak: Diagnosis dan tatalaksana. Dalam: Mexitalia M, Kusumawati NR, Sareharto TP, Rini AE, penyunting. Simposium sehari tentang mengelola pasien anak dalam praktek sehari-hari; Semarang, Juni 11, 2011. Semarang: Universitas Diponegoro; 2011:25-40.

17. Guldan GS, Fan HC, Xiao M, Ni ZZ, Xiang X and Tang MZ. Culturally Appropriate Nutrition Education Improves Infant Feeding and Growth in Rural Sichuan. China J Nutr 2000;130:1204-11. 
Darwati dkk: Pengaruh intervensi konseling feeding rules dan stimulasi terhadap status gizi dan perkembangan anak

18. Yuniastuti A. Gizi dan kesehatan. Yogyakarta: Graha Ilmu; 2008.h.118-20.

19. Kadarhadi, Elva. Pengaruh konseling dengan "feeding rules" terhadap status gizi anak dengan kesulitan makan. Semarang : Program Pendidikan Sarjana Kedokteran. Fakultas Kedokteran Universitas Diponegoro, 2012.

20. Aminah, Mimin, Judiono. Pengaruh intervensi (konseling dan stimulasi) terhadap perkembangan dan status gizi balita di wilayah Kota Cimahi. Jurnal Kedokteran dan Kesehatan 2008;1:34-46.

21. Jalal, Fasli. Pengaruh gizi dan stimulasi psikososial terhadap pembentukan kecerdasan anak usia dini: agenda pelayanan tumbuh kembang anak holistik-integratif [Pidato Pengukuhan]. Padang: Universitas Andalas; 2009.

22. Kementerian Perencanaan Pembangunan Nasional/ BAPPENAS. Rencana Aksi Nasional Pangan dan Gizi 2011-2015. Jakarta: Kementerian Perencanaan Pembangunan Nasional/BAPPENAS; 2011.

23. Maritalia, Dewi. Analisis pelaksanaan program stimulasi, deteksi dan intervensi dini tumbuh kembang (SDIDTK) balita dan anak pra sekolah di Puskesmas Kota Semarang Tahun 2009. [Thesis]. Semarang : Program Pascasarjana Universitas Diponegoro, 2009. 